\title{
Elderly care in the emergency department: an integrative review
}

\section{Abstract}

Objective: To identify the care practices of nurses for the elderly in emergency departments. Method: An integrative review was carried out in the CAPES database, selecting publications in English, Portuguese and Spanish published between January 2011 and October 2016. The descriptors used were: "Emergency nursing"; "Geriatric nursing"; "Health services for the elderly"; "Elderly person"; "Nursing care". Results: Sixteen articles were analyzed in English, the majority of which had a qualitative approach (56.2\%). Australia had the largest number of publications $(31.2 \%)$. After reading the studies in full, the common themes were organized and classified into three categories: Challenges/difficulties in the care of the elderly in the emergency department, Positive experiences of elderly care in the emergency department and The emergency department as a space of death and dying. Conclusion: The care practices of nurses are focused on identifying the main problems regarding elderly care, adaptation and the planning of their work routine. Another strategy is the implementation of instruments of evaluation specific to elderly patients and the involvement of the family in all stages of care.
Keywords: Emergency Nursing. Geriatric Nursing. Health Services for the Aged. Elderly. Nursing Care.

\footnotetext{
Universidade Federal do Paraná (UFPR), Setor de Ciências da Saúde, Programa de Pós-graduação Mestrado Profissional em Enfermagem. Curitiba, Paraná, Brasil.

2 Universidade Federal do Paraná (UFPR), Setor de Ciências da Saúde, Departamento de Enfermagem. Curitiba, Paraná, Brasil.
}

Luciana Aparecida Soares de Andrade' Sulamita de Paula Santos ${ }^{1}$ Roselene Campos Corpolato' Mariluci Hautsch Willig² Maria de Fátima Mantovani² Alessandra Luciana Aguilera' 


\section{INTRODUCTION}

The need for emergency care of the elderly has gradually increased due to population aging and a changing epidemiological profile ${ }^{1}$. A study carried out in emergency departments in the USA found that the elderly, especially those over 75 years old, have a higher admission rate for emergencies than other age groups, a rate that is likely to increase as the population ages ${ }^{2}$.

Increased life expectancy can result in the occurrence of problems arising from morphophysiological changes inherent to aging, leading to an increase in chronic diseases, morbidity and functional disability ${ }^{1}$. The elderly are therefore more likely to seek emergency care, and are usually admitted to the hospital twice as often as younger individuals ${ }^{2}$. As the elderly suffer from more complex health problems they need specialized care and therefore represent the most frequent users of the main health services ${ }^{3,4}$.

This is due to the clinical heterogeneity of these patients, which combined with a depletion of physiological reserves and diminished cognitive capacity results in the atypical manifestation of common diseases, casting doubts over the efficacy of standard approaches and representing a challenge for the implementation of care by emergency department nurses ${ }^{2}$. The objective of the present study was therefore to identify the care practices performed by nurses for elderly persons receiving care in emergency departments.

\section{METHOD}

An integrative review was carried out in accordance with the six methodological steps proposed by Mendes et al. ${ }^{5}$ In the first step the following guiding question was defined: what are the nursing care practices for elderly persons receiving treatment in emergency departments described in Brazilian and nonBrazilian nursing publications in the last five years?

In the second stage the following inclusion criteria were established: complete articles in English, Portuguese and Spanish available online, published from January 2011 to September 2016, which addressed nursing care for the elderly treated in emergency departments. The exclusion criteria were: systematic, integrative reviews, case studies, reports of experiences and editorials.

In the third step, it was decided that the online search platform of the Coordination for the Improvement of Higher Education Personnel (CAPES) would be used to research scientific productions, as this encompasses several Brazilian and non-Brazilian databases and is available for public access. The online search occurred in October 2016, using the following descriptors: emergency nursing, geriatric nursing, nursing care, the elderly, health services for the elderly, emergencies, geriatric hospitals. To search for articles, the following combinations of descriptors in Portuguese, English and Spanish were used: "emergency nursing" AND "elderly", "emergency nursing" AND "health services for the elderly", "emergencies" AND "elderly", "emergencies AND "geriatric nursing", "nursing care" AND "elderly", "health services for the elderly" AND "emergencies", "geriatric hospitals" AND "emergencies".

Firstly, two researchers independently evaluated the titles and abstracts of the publications in the database for the selection of potentially eligible studies. From these, full texts were obtained for a thorough reading. Afterwards, those that did not meet the inclusion criteria were excluded. The flowchart of the article selection process based on the PRISMA ${ }^{6}$ model is shown in Figure 1.

In the fourth stage data analysis was performed, organized by categories. In the fifth stage the discussion was developed according to the pertinent literature and in the sixth stage the synthesis of the review was elaborated.

\section{RESULTS}

The sample consisted of 16 articles in English, with eight $(50.0 \%)$ qualitative, seven (43.8\%) quantitative and one $(6.2 \%)$ mixed approach studies. In relation to the year of publication, four $(25.0 \%)$ articles were published in 2015; three (18.7\%) in the years 2011, 2013 and 2014; two (12.5\%) in 2012 and 
one $(6.25 \%)$ in 2016 . Australia had the largest number of publications on the subject, with $31.2 \%$, followed by Canada with $18.8 \%$, and the USA and Spain both with $12 \%$ each. Also included were articles from other countries such as Finland, Switzerland, Sweden and England, which accounted for 26.0\%. The articles were published in 15 journals, with
International Emergency Nursing publishing the most articles $(12.0 \%)$ (Chart 1).

The topics covered in the studies were classified into three categories: Challenges/difficulties in care for the elderly, Positive experiences of care for the elderly and the Emergency department as a place of death / dying.
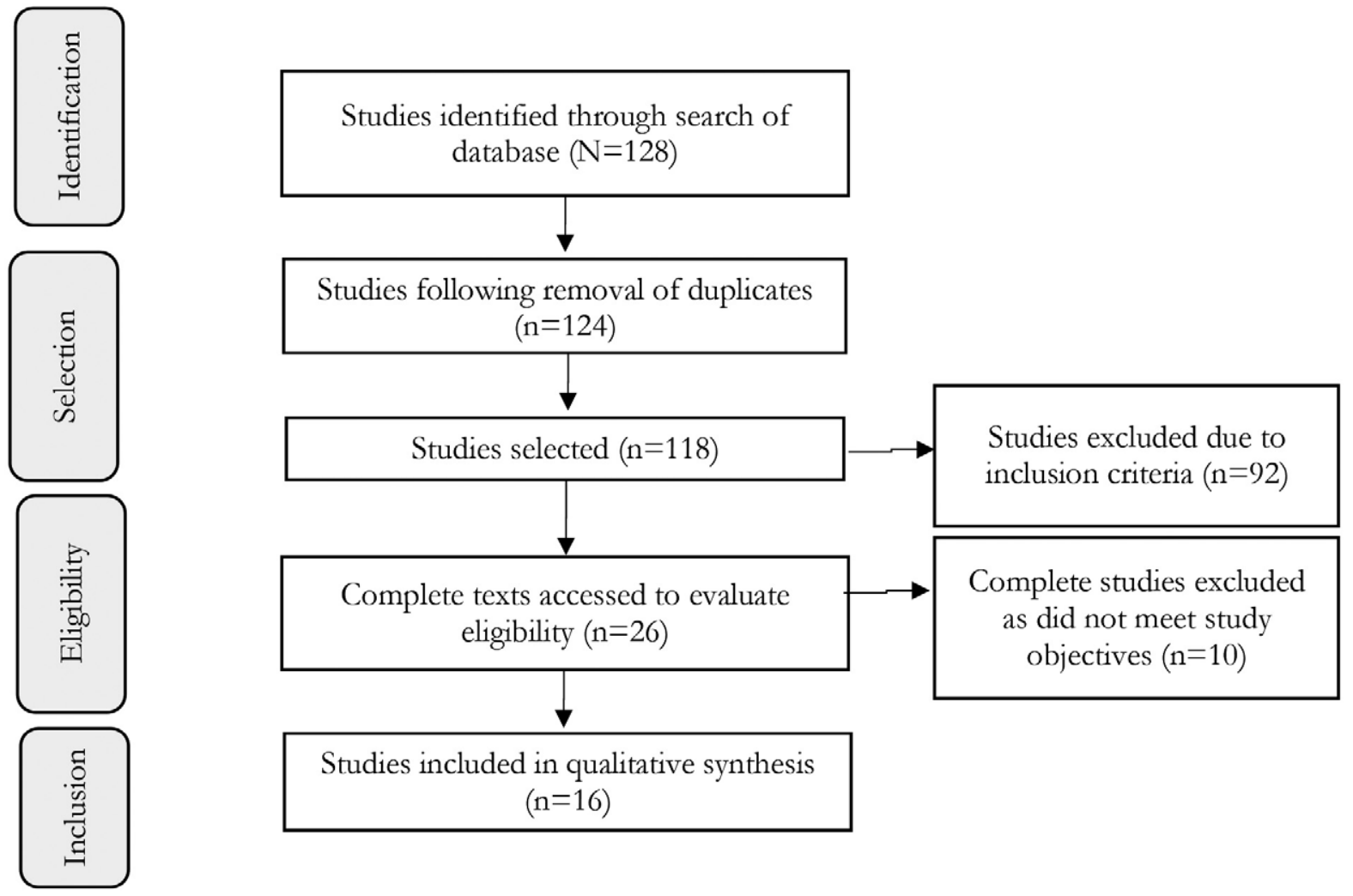

Figure 1. Flowchart of selection of publications for integrative review, based on PRISMA model ${ }^{6}$. Curitiba, Paraná, 2017.

Chart 1. Results of study. Curitiba, Paraná, 2017.

\begin{tabular}{|l|l|l|l|}
\hline Title & Periodical & Objectives & Synthesis of results \\
\hline $\begin{array}{l}\text { 1. In-reach nursing } \\
\text { services improve older } \\
\text { patient outcomes and } \\
\text { access to emergency } \\
\text { care }^{29} .\end{array}$ & $\begin{array}{l}\text { Australasian } \\
\text { Journal On } \\
\text { Ageing }\end{array}$ & $\begin{array}{l}\text { Identify the impact of } \\
\text { basic care performed } \\
\text { by the specialized } \\
\text { nursing service on } \\
\text { the clinical results } \\
\text { of elderly patients } \\
\text { from long-term care } \\
\text { facilities treated at the } \\
\text { emergency department, } \\
\text { before and after the } \\
\text { implementation of the } \\
\text { service. }\end{array}$ & $\begin{array}{l}\text { The average length of stay in the emergency } \\
\text { department decreased by 24 minutes and the } \\
\text { hospitalization rate by 23\%. The proportion } \\
\text { of people who returned to the emergency } \\
\text { department within six months decreased by } \\
12 \% \text {. The proportion of hospitalized patients } \\
\text { discharged with a palliative care plan increased } \\
\text { by } 13 \% \text {. There was a significant decrease in } \\
\text { the average length of hospitalization, fewer } \\
\text { hospitalizations of patients coming from long } \\
\text { hospitalizations after the implementation of } \\
\text { the primary care/follow-up service. }\end{array}$ \\
\hline
\end{tabular}


Continuation of Chart 1

\begin{tabular}{|c|c|c|c|}
\hline Title & Periodical & Objectives & Synthesis of results \\
\hline $\begin{array}{l}\text { 2. Referrals to } \\
\text { hospital emergency } \\
\text { departments from } \\
\text { residential aged care } \\
\text { facilities: stuck in a } \\
\text { time warp }{ }^{14} \text {. }\end{array}$ & $\begin{array}{l}\text { Contemporary } \\
\text { Nurse }\end{array}$ & $\begin{array}{l}\text { Characterize elderly } \\
\text { persons admitted to } \\
\text { emergency services } \\
\text { from long-term care } \\
\text { facilities and to explore } \\
\text { the perception of } \\
\text { nurses of the reasons } \\
\text { why these "residents" } \\
\text { are referred to the } \\
\text { emergency department. }\end{array}$ & $\begin{array}{l}\text { The main themes identified are related to } \\
\text { professional competence, lack of equipment } \\
\text { in nursing homes, relatives and residents } \\
\text { requesting referrals, communication } \\
\text { difficulties and poor team attitude. It is } \\
\text { important to use strategies for the detection of } \\
\text { residents with deteriorating conditions and to } \\
\text { provide prompt care for the same. }\end{array}$ \\
\hline $\begin{array}{l}\text { 3. Respect in the care } \\
\text { of older patients in } \\
\text { acute hospitals }{ }^{30} \text {. }\end{array}$ & Nursing Ethics & $\begin{array}{l}\text { To describe the } \\
\text { experiences of elderly } \\
\text { patients and their } \\
\text { relatives in relation to } \\
\text { the respect shown in } \\
\text { the care offered at an } \\
\text { acute care hospital. }\end{array}$ & $\begin{array}{l}\text { The concept of respect can be defined through } \\
\text { the actions taken by nurses (kindness, patience } \\
\text { when listening, trust, response to information } \\
\text { needs, assistance with basic needs, pain relief, } \\
\text { response to requests and time management), } \\
\text { through the family (support, care and } \\
\text { protection of the patient's interests) and by } \\
\text { environmental factors (such as the valuation of } \\
\text { the elderly by society, management of health } \\
\text { organizations, the culture of nursing, the flow } \\
\text { of information and patient accommodation)). }\end{array}$ \\
\hline $\begin{array}{l}\text { 4. Geriatric screening } \\
\text { tools to select older } \\
\text { adults susceptible } \\
\text { for direct transfer } \\
\text { from the emergency } \\
\text { department to } \\
\text { subacute intermediate- } \\
\text { care hospitalization }{ }^{16} \text {. }\end{array}$ & $\begin{array}{l}\text { Journal of } \\
\text { the American } \\
\text { Medical } \\
\text { Directors } \\
\text { Association - } \\
\text { JAMDA }\end{array}$ & $\begin{array}{l}\text { Evaluate whether easy, } \\
\text { fast and inexpensive } \\
\text { geriatric tracking tools } \\
\text { predict a discharge } \\
\text { outcome other than } \\
\text { returning to the } \\
\text { previous condition for } \\
\text { patients admitted to a } \\
\text { subacute/ intermediate } \\
\text { care department. }\end{array}$ & $\begin{array}{l}\text { Among the geriatric screening tools, the ISAR } \\
\text { - Identification of Seniors at Risk was used } \\
\text { independently in the discharge of patients } \\
\text { transferred from the emergency department } \\
\text { to intermediate care. Predictive validity was } \\
\text { poor. More research is needed on the selection } \\
\text { of candidates for alternatives to conventional } \\
\text { hospitalization. }\end{array}$ \\
\hline $\begin{array}{l}\text { 5. Impact of } \\
\text { observation on } \\
\text { disposition of elderly } \\
\text { patients presenting } \\
\text { to emergency } \\
\text { departments with non- } \\
\text { specific complaints }{ }^{18} \text {. }\end{array}$ & Plos One & $\begin{array}{l}\text { Prospective study of } \\
\text { the referral process of } \\
\text { patients treated in the } \\
\text { emergency department } \\
\text { with nonspecific } \\
\text { complaints. }\end{array}$ & $\begin{array}{l}\text { Planning for optimum referral of patients with } \\
\text { nonspecific complaints improves after the } \\
\text { observation period if it is strictly defined in } \\
\text { relation to the hospitalization of patients with } \\
\text { acute morbidities. }\end{array}$ \\
\hline $\begin{array}{l}\text { 6. Patient transfer } \\
\text { forms enhance key } \\
\text { information between } \\
\text { nursing homes } \\
\text { and emergency } \\
\text { department }{ }^{20} \text {. }\end{array}$ & $\begin{array}{l}\text { Geriatric } \\
\text { Nursing }\end{array}$ & $\begin{array}{l}\text { To assess the extent } \\
\text { to which transfer } \\
\text { forms facilitate } \\
\text { communication } \\
\text { between the employees } \\
\text { of a long-term facility } \\
\text { for the elderly and the } \\
\text { emergency department } \\
\text { based on the criteria } \\
\text { proposed by Terrell } \\
\text { and Miller. }\end{array}$ & $\begin{array}{l}\text { During the study period there were } 306 \text { patient } \\
\text { transfers. Transfer forms were used in } 157 \text { cases. } \\
\text { The results suggest that information considered } \\
\text { valuable for the benefit of a patient in the } \\
\text { emergency department has a greater chance of } \\
\text { being acknowledged when using transfer forms. } \\
\text { However, the availability of this information } \\
\text { does not translate into observable differences } \\
\text { in the case of time resolution and referrals. The } \\
\text { forms reinforce the communication between } \\
\text { the long-term institution and the emergency } \\
\text { department. Essential information for } \\
\text { emergency patient care is significantly increased } \\
\text { with the use of the transfer form. }\end{array}$ \\
\hline
\end{tabular}


Continuation of Chart

\begin{tabular}{|c|c|c|c|}
\hline Title & Periodical & Objectives & Synthesis of results \\
\hline $\begin{array}{l}\text { 7.Implementation } \\
\text { and effectiveness } \\
\text { of 'care navigation', } \\
\text { coordinated } \\
\text { management for } \\
\text { people with complex } \\
\text { chronic illness: } \\
\text { rationale and methods } \\
\text { of a randomised } \\
\text { controlled trial }{ }^{31} \text {. }\end{array}$ & $\begin{array}{l}\text { Health Services } \\
\text { Research - } \\
\text { BMC }\end{array}$ & $\begin{array}{l}\text { Measure the impact } \\
\text { of coordinated care } \\
\text { interventions through } \\
\text { the Care Navigation } \\
\text { method on the use of } \\
\text { health services and } \\
\text { quality of life in elderly } \\
\text { patients with chronic } \\
\text { diseases over two years. }\end{array}$ & $\begin{array}{l}\text { This study of mixed methods informs } \\
\text { the generality and sustainability of care } \\
\text { coordination programs in Australia and } \\
\text { internationally. The Care Navigation trial } \\
\text { aims to develop these principles to provide a } \\
\text { comprehensive program of coordinated care to } \\
\text { improve health outcomes among patients with } \\
\text { chronic disease. }\end{array}$ \\
\hline $\begin{array}{l}\text { 8. Dying cases in } \\
\text { emergency places: } \\
\text { Caring for the } \\
\text { dying in emergency } \\
\text { departments }{ }^{12} \text {. }\end{array}$ & $\begin{array}{l}\text { Social Science } \\
\text { \& Medicine }\end{array}$ & $\begin{array}{l}\text { Investigate end of life } \\
\text { care in an emergency } \\
\text { department. }\end{array}$ & $\begin{array}{l}\text { Evidence was found for the importance of } \\
\text { the role of the nurse in modifying practices } \\
\text { and improving the quality of end-of-life } \\
\text { care through patient liaison, effective } \\
\text { communication, and patient-centered care. }\end{array}$ \\
\hline $\begin{array}{l}\text { 9. During and beyond } \\
\text { the triage encounter: } \\
\text { Chronically ill elderly } \\
\text { patients' experiences } \\
\text { throughout their } \\
\text { emergency department } \\
\text { attendances }{ }^{21} \text {. }\end{array}$ & $\begin{array}{l}\text { International } \\
\text { Emergency } \\
\text { Nursing }\end{array}$ & $\begin{array}{l}\text { Explore and describe } \\
\text { the experiences of a } \\
\text { group of chronically ill } \\
\text { elderly patients cared } \\
\text { for in the emergency } \\
\text { department. }\end{array}$ & $\begin{array}{l}\text { The elderly perceived care in the emergency } \\
\text { sector as a contradictory event. The initially } \\
\text { receive fast and efficient care during triage, } \\
\text { but then receive indifferent and inattentive } \\
\text { behavior by the nurses. }\end{array}$ \\
\hline $\begin{array}{l}\text { 10. Emergency nurses' } \\
\text { perceptions of the role } \\
\text { of confidence, self- } \\
\text { efficacy and reflexivity } \\
\text { in managing the } \\
\text { cognitively impaired } \\
\text { older person in pain }{ }^{32} \text {. }\end{array}$ & $\begin{array}{l}\text { Journal of } \\
\text { Clinical } \\
\text { Nursing }\end{array}$ & $\begin{array}{l}\text { To explore the } \\
\text { practices of emergency } \\
\text { nurses in the care of } \\
\text { elderly people with } \\
\text { cognitive deficits and } \\
\text { long bone fracture pain } \\
\text { to assess confidence } \\
\text { and self-efficacy. }\end{array}$ & $\begin{array}{l}\text { Confidence, self-efficacy and reflexivity } \\
\text { allowed the provision of appropriate, timely } \\
\text { and compassionate care. Confidence and } \\
\text { self-efficacy in nursing practices were based } \\
\text { on clinical and reflexive experience and } \\
\text { were crucial for the acquisition of skills and } \\
\text { knowledge. }\end{array}$ \\
\hline $\begin{array}{l}\text { 11. Facilitators and } \\
\text { barriers to safe } \\
\text { emergency department } \\
\text { transitions for } \\
\text { community dwelling } \\
\text { older people with } \\
\text { dementia and their } \\
\text { caregivers: A social } \\
\text { ecological study }{ }^{33} \text {. }\end{array}$ & $\begin{array}{l}\text { International } \\
\text { Journal of } \\
\text { Nursing } \\
\text { Studies }\end{array}$ & $\begin{array}{l}\text { Identify factors that } \\
\text { facilitate or prevent } \\
\text { safe care transitions } \\
\text { for elderly people } \\
\text { with dementia in two } \\
\text { emergency sectors. }\end{array}$ & $\begin{array}{l}\text { Four categories were identified: under-triaged; } \\
\text { waiting and worrying about what was wrong; } \\
\text { time pressure with a lack of care for basic } \\
\text { needs; and relationships and interactions } \\
\text { leading to feeling ignored, forgotten and } \\
\text { unimportant. These consequences arise from } \\
\text { a triage system that does not recognize the } \\
\text { atypical presentation of disease and illness. } \\
\text { This results in a cascade of vulnerability in } \\
\text { elderly people with dementia. }\end{array}$ \\
\hline $\begin{array}{l}\text { 12. Geriatric } \\
\text { emergency nurses: } \\
\text { addressing the } \\
\text { needs of an aging } \\
\text { population }{ }^{15} \text {. }\end{array}$ & $\begin{array}{l}\text { Journal Of } \\
\text { Emergency } \\
\text { Nursing }\end{array}$ & $\begin{array}{l}\text { Describe the } \\
\text { innovative role of } \\
\text { emergency nursing } \\
\text { implemented to meet } \\
\text { the needs of the elderly } \\
\text { in the emergency } \\
\text { department. }\end{array}$ & $\begin{array}{l}\text { Three themes emerged: defining the role and } \\
\text { its functions; a collaborative relationship: } \\
\text { tailoring the same to the emergency } \\
\text { department and recommendations for future } \\
\text { role development. }\end{array}$ \\
\hline
\end{tabular}


Continuation of Chart 1

\begin{tabular}{|c|c|c|c|}
\hline Title & Periodical & Objectives & Synthesis of results \\
\hline $\begin{array}{l}\text { 13. Nurses' } \\
\text { experiences of caring } \\
\text { for the older adult } \\
\text { in the emergency } \\
\text { department: A focused } \\
\text { ethnography }{ }^{34} \text {. }\end{array}$ & $\begin{array}{l}\text { International } \\
\text { Emergency } \\
\text { Nursing }\end{array}$ & $\begin{array}{l}\text { Investigate the } \\
\text { experiences of } \\
\text { nurses caring for } \\
\text { elderly persons in the } \\
\text { emergency department. }\end{array}$ & $\begin{array}{l}\text { Three themes were identified: the culture of } \\
\text { the emergency sector, care organized according } \\
\text { to a pattern of priorities; the care of the elderly } \\
\text { does not fit into this culture; managing the } \\
\text { lack of adjustments between the elderly and } \\
\text { the emergency sector, puts the elderly at risk of } \\
\text { precarious care. }\end{array}$ \\
\hline $\begin{array}{l}\text { 14. Results of a } \\
\text { national survey of } \\
\text { Australian nurses' } \\
\text { practice caring } \\
\text { for older people } \\
\text { in an emergency } \\
\text { department }^{8} \text {. }\end{array}$ & $\begin{array}{l}\text { Journal of } \\
\text { Clinical } \\
\text { Nursing }\end{array}$ & $\begin{array}{l}\text { To report the practices } \\
\text { of Australian nurses in } \\
\text { the care of the elderly } \\
\text { in the emergency } \\
\text { department. }\end{array}$ & $\begin{array}{l}\text { Nurses use positive clinical practices and } \\
\text { understand that patient-centered care can } \\
\text { reduce adverse events and length of stay in } \\
\text { the emergency department. It is important to } \\
\text { improve language and tone in clinical practice. }\end{array}$ \\
\hline $\begin{array}{l}\text { 15. Screening for fall } \\
\text { risks in the emergency } \\
\text { department: a novel } \\
\text { nursing-driven } \\
\text { program?. }\end{array}$ & $\begin{array}{l}\text { Brief Research } \\
\text { Report }\end{array}$ & $\begin{array}{l}\text { To describe the use of } \\
\text { TUGT in evaluations } \\
\text { carried out by } \\
\text { geriatric nurses in the } \\
\text { emergency department. }\end{array}$ & $\begin{array}{l}\text { The evaluation of gait with the Timed Up and } \\
\text { Go Test (TUGT) was performed in } 443 \text { elderly } \\
\text { people, of whom } 368 \text { had a positive result, i.e. } \\
\text { it took more than } 12 \text { seconds to complete the } \\
\text { three-meter walk. Interventions for positive } \\
\text { outcomes included physical therapy }(17.1 \%) \text {, } \\
\text { outpatient visits with physical therapy }\left(12.2^{\%} \% \text {, }\right. \\
\text { and social work and consultation }(44.0 \%) \text {. }\end{array}$ \\
\hline $\begin{array}{l}\text { 16. Undertriage in } \\
\text { older emergency } \\
\text { department patients } \\
\text { - tilting against } \\
\text { windmills }{ }^{17} \text {. }\end{array}$ & Plos One & $\begin{array}{l}\text { To test whether a } \\
\text { teaching intervention } \\
\text { had a long-term } \\
\text { sustainable effect on } \\
\text { reducing undertriage } \\
\text { rates in elderly patients. }\end{array}$ & $\begin{array}{l}\text { A total of } 519 \text { patients were evaluated before } \\
\text { and } 394 \text { after the intervention. It was observed } \\
\text { that the knowledge among nurses of triage was } \\
\text { already high before the teaching intervention. } \\
\text { The prevalence of undertriaged patients was } \\
22.5 \% \text { before the intervention and } 24.2 \% \\
\text { one year after the intervention. The teaching } \\
\text { intervention was not significant. Undertriage is } \\
\text { not merely a matter of actual knowledge. }\end{array}$ \\
\hline
\end{tabular}

\section{DISCUSSION}

\section{Challenges/difficulties in care for the elderly}

The results show that the profile of care in the emergency departments is changing as a consequence of population aging, with the number of elderly people seeking this service gradually increasing ${ }^{7,9}$. Although these patients are treated by pre-hospital and primary care services, the hospital emergency department is the most frequently used in cases of health problems ${ }^{10}$.

A documentary study on the identification of health problems that led the elderly to seek treatment in the emergency departments of two public hospitals in Rio de Janeiro showed that most were suffering from more than one basic disease, which was the main reason for seeking care ${ }^{11}$. An aggravating factor is that these patients are admitted with more serious health problems, as their disease is combined with several comorbidities ${ }^{12}$, which increases the risk of mortality, the length of stay in the emergency department and the number of hospitalizations ${ }^{13,14}$.

This situation indicates that more and more of the work of nurses in the emergency department includes care for the elderly. Thus, care priorities must be continually rethought ${ }^{13}$ as admission to the emergency sector exposes these patients to the risk of functional decline and incidents arising from the care itself ${ }^{7,15}$. Unfavorable outcomes such as delirium and death may increase when the hospitalization of elderly patients occurs in non-specialized settings ${ }^{16}$. 
Elderly care in the emergency sector is a challenge for nurses and begins with triage ${ }^{17}$. It includes difficulties in assessment and diagnosis due to atypical presentation of symptoms, the presence of multiple comorbidities, changes in mental state and communication difficulties ${ }^{7,18}$. In this sense, health care professionals must invest in the communication process to allow effective and efficient care ${ }^{19}$.

The establishment of satisfactory communication begins in the patient's first contact with the nurse, usually when the patient undergoes triage. Inadequate triage can increase the risk of deterioration of the health status of the patient while they wait for care. In this aspect the elderly represent a vulnerable group and are more susceptible to undertriage due to the atypical manifestation of diseases and difficulties in interpreting the vital signs, which may appear normal even in cases of severe disease ${ }^{17}$.

Although training and skills in emergency care allow nurses to quickly recognize a critical illness, they may have difficulty detecting a problem in elderly patients because of the complexity of some chronic conditions ${ }^{8,12}$.

An integral approach to older patients requires critical thinking skills to minimize adverse events and prolonged hospitalization, as well as planning and organizing skills for care. While nurses are competent at providing emergency care, they may exhibit limitations when addressing the complex needs of the elderly ${ }^{8}$.

Additionally, a study carried out in Spain in 2014 revealed that the characteristics of the environment, such as excess numbers of patients awaiting care, a shortage of health professionals and a lack of physical space can influence the decision making of professionals and, consequently, the care offered, which can compromise the physical integrity of the patient $t^{17}$.

Another difficulty faced by nurses relates to the transfer of care of the elderly, which involves a set of actions aimed at allowing the safe and timely passage of users between different health sectors and services. As they can suffer from several chronic diseases with different treatments, elderly patients are often treated by many health services.
However, the transfer of patient care information between services usually fails to happen, resulting in the elderly person being returned to emergency departments and leading to further hospitalizations and the occurrence of adverse events ${ }^{7,15,20}$. The implementation of instruments that enable the transfer of patient information is of great importance if continuity of care is to be ensured.

The emergency department is a dynamic environment in which there is pressure for tasks to be executed in a timely manner due to the severity of cases and the number of patients waiting for treatment ${ }^{13}$. In this environment, in which new patients are continuously admitted, elderly persons waiting for a hospital bed are no longer a priority for nurses, who direct their attention to those in life-threatening situations ${ }^{13}$.

As a consequence, elderly persons undergo a contradictory experience in the emergency department, as they are initially the focus of the nurse's attention, before being left to one side and having their care needs, such as assistance to get up and go to the bathroom, ignored ${ }^{13,21}$. In this way, the environment can result in stress for the elderly and cause episodes of confusion due to its fast pace ${ }^{8}$.

These findings indicate the need to restructure the working processes of the emergency department to ensure care that meets the needs of the elderly.

Positive experiences of care for the elderly

Emergency departments follow a curative model aimed at quick treatment and short stays. However, this model is inconsistent with the management of care for elderly persons with chronic and complex conditions, which requires health services based on health care models that encompass their biopsychosocial needs ${ }^{8}$.

Changing this model is a long process which begins when professionals first become aware of its problems. A study of nurses from an emergency department in Australia in 2016 revealed that, even though there was no specific evaluation of elderly persons, such professionals identified their main 
care-related problems as being adequate pain control, hygiene, psychosocial care and the maintenance of the patient's independence ${ }^{8}$.

Becoming aware of the problems they faced led nurses to seek new practices such as using appropriate language when talking to the elderly without labeling them, promoting patient independence, and performing close observation ${ }^{8}$. Another key element is confidence and self-efficacy, which need to be strengthened by nurses in the emergency department to ensure appropriate, timely and compassionate care $^{12}$.

Respectful actions, honest and understandable information and allowing patients to express their opinions and anxieties are fundamental actions in the emergency department. It is essential that nurses approach family members, as when an elderly person cannot provide accurate information about their health status and participate in the decision-making process, the family must assume this role ${ }^{8,15}$.

Two-thirds of patients admitted to the emergency department suffer cognitive impairment and are unable to describe their personal history and the medications they use or provide information about allergies and the dates and reasons for recent hospitalizations. The use of forms, such as discharge summaries that contain records of the history of hospital visits by the elderly, improves the transmission of essential information to the nurses who admit the patients to the emergency department ${ }^{20}$.

Access to accurate patient information can help nurses identify their limitations and plan care with an emphasis on promoting autonomy. Although it takes up time, the benefits of this practice are vital to prevent the patient from becoming dependent on intensive care ${ }^{21}$.

In this process the elderly and their families can be considered as active agents in the construction of care, with the family assuming the role of supervising health status, making decisions and accompanying their loved one ${ }^{22,23}$. Therefore, the elderly and their family require special attention from the nurse, which contributes to the development of a relation of trust and respect and to quality and humanized care ${ }^{24}$.
Studies have also reported the use of tools for evaluating the elderly as an element that can contribute to the improvement of care in the emergency department and the targeting of the interventions to which the elderly should be submitted. One of the tools identified in the studies is the Timed Up and Go test, which evaluates the gait and balance of the elderly, which are predictive elements for the risk of falls. The author states that approximately one third of individuals over 65 years old will fall at least once a year, with such incidents resulting in fractures, surgeries, hospital admissions, prolonged rehabilitation and death?

Falls are common events among the elderly population and progressively increase with age, due to reduced muscle strength, changes in gait and maintenance of posture, resulting in a greater chance of stumbling and falling. They represent a public health problem, as they can result in fractures and injuries, which results in a need for emergency department care and even hospitalization ${ }^{25}$.

A study carried out in the municipality of Barbacena (Minas Gerais) in 2015 found that 31.08\% of patients who had fallen in the previous year were hospitalized. In addition to the psychosocial consequences, after a fall the elderly experience feelings of fear, frailty and a lack of confidence, which represent the beginning of the degeneration of their overall health ${ }^{25}$.

The emergency sector can act in the prevention of these falls and alter the trajectory of the functional decline of the elderly, identifying individuals with a high risk of falls when they seek care. The application of the Timed Up and Go Test (TUGT) test is feasible and inexpensive as it can be performed by nurses, and its results allow the creation of a mobility care plan to change the trajectory of functional decline among the elderly?

\section{The emergency department as a space of death/dying}

In contemporary society, death has been transferred to the hospital, which in turn has become legitimized as a place to $\mathrm{die}^{26}$. Thus, caring for the end-of-life patient in the emergency department 
has become more frequent. A study performed in the emergency department of a São Paulo hospital showed that the higher the level of care required by the patient, the higher the percentage of death ${ }^{27}$.

Advances in technology and the improvement of health knowledge have enabled people with multiple comorbidities to live for a long time, leading to an increase in life expectancy, as well as an increased need for care in the latter stages of life ${ }^{12}$.

Emergency departments, as the gateway to hospital care, have become an environment of palliative care. In this way, professionals and patients experience the experience of caring for and being cared for in spaces that were originally designed to save lives ${ }^{12}$.

Death is seen as dirty and inconvenient by society ${ }^{26}$. This connotation contradicts the idealization of the emergency sector as a clean location where the fight for life is carried out on a daily basis. Consequently, the approach taken to caring for the elderly at the end of life often falls short of the expectations of the dying patient and their relatives ${ }^{12}$.

Even if the death/dying process is solitary, it must be experienced by the patient with care, comfort and comfort offered by prepared professionals who are aware of the pain and suffering that surrounds them, so that the dignity of the patient is preserved, regardless of where they are receiving $\mathrm{care}^{28}$. Although nurses believe that the emergency sector is an unsuitable place to care for terminally ill elderly persons, ${ }^{8}$ they have a role in challenging existing practices and improving quality of end-of-life care ${ }^{12}$.

One of the limitations of the present study is that only the search platform of the Coordination for the
Improvement of Higher Level Personnel (CAPES) was used to seek scientific productions. The survey included publications from different countries, however, diversifying the sample in relation to cultural, political and social aspects, which directly or indirectly influence the care actions performed by nurses.

\section{CONCLUSION}

The emergency department has become the main point of access of the growing elderly population with multiple comorbidities and chronic diseases, evidencing the need to change the paradigm of care. Nursing care practices carried out by nurses in such departments are aimed at adapting their routine and work structure to meet the needs of these patients.

Nurses face a number of difficulties in this process, however. These include the physiological changes of aging, which interfere with how diseases manifest themselves, and a lack of knowledge about how to interpret these manifestations; communication barriers, especially in relation to elderly persons suffering cognitive decline; a lack of adequate physical structures; and the increased time spent evaluating patients and performing care, especially as the dynamics of emergency work rarely allow them to devote more time to the elderly.

These difficulties have challenged nurses to rethink the care they provide. The starting point has been the identification of the main problems related to caring for the elderly, the implementation of specific instruments of evaluation and the involvement of the family in care. Communication is the principal means of achieving these goals.

\section{REFERENCES}

1. Berlize EM, Farias AM, Dalazen F, Oliveira KR, Pillatt AP, Fortes CK. Analysis of the functional capacity of elderly residents of communities with a rapid population aging rate. Rev Bras Geriatr Gerontol [Internet]. 2016 [acesso em 20 ago. 2017];19(4):643-52. Disponível em: http://www. scielo.br/scielo.php?script=sci_arttext\&pid=S1809$98232016000400643 \& \operatorname{lng}=$ en\&tlng=en

2. Rosenberg M, Rosenberg L. The geriatric emergency department. Emerg Med Clin North AM [Internet]. 2016 [acesso em 21 fev. 2017];34(3):629-48.

Disponível em: https://www.sciencedirect.com/ science/article/pii/S0733862716300268?via\%3Dihub 
3. Oliveira MR, Renato PV, Cordeiro HPC, Pasinato MT. A mudança de modelo assistencial de cuidado ao idoso na Saúde Suplementar: identificação de seus pontos-chave e obstáculos para implementação. Physis [Internet]. 2016 [acesso em 14 set. 2016];26(4):1383-94. Disponível em: http://www. scielo.br/scielo.php?script=sci_arttext\&pid=S010373312016000401383\&lng=pt\&tlng=pt

4. Sanon M, Baumlin KM, Kaplan SS, Grudzen CR Care and respect for elders in emergencies program: a preliminary report of a volunteer approach to enhance care in the emergency department. J Am Geriatr Soc [Internet]. 2014 [acesso em 18 set. 2016];62(2):365-70. Disponível em: https://www.ncbi. nlm.nih.gov/pubmed/24428229

5. Mendes KDS, Silveira RCCP, Galvão MG. Revisão integrativa: método de pesquisa para a incorporação de evidências na saúde e na enfermagem. Texto \& Contexto Enferm [Internet]. 2008 [acesso em 15 dez. 2015];17(4):758-64. Disponível em: http://www.scielo.br/scielo.php?pid=S010407072008000400018\&script=sci_arttext\&tlng=pt

6. Moher D, Liberati A, Tetzlaff J, Altman DG; PRISMA Group. Preferred reporting items for systematic reviews and meta-analyses: the PRISMA statement. PLoS Med [Internet]. 2009 [acesso em 31 jan. 2017];151(4):264-9. Disponível em: http://www. ncbi.nlm.nih.gov/pmc/articles/PMC2707599/

7. Santos MT, Lima MADS, Zucatti PB. Elder-friendly emergency services in Brazil: necessary conditions for care. Rev Esc Enferm USP [Internet]. 2016 [acesso em 10 ago. 2017];50(4):592-9. Disponível em: http://www. scielo.br/scielo.php?script $=$ sci_arttext\&pid $=\mathrm{S} 0080$ 62342016000400594\&lng=en\&tlng=en

8. Deasey D, Kable A, Jeong S. Results of a national survey of australian nurses' practice caring for older people in an emergency department. J Clin Nurs [Internet]. 2016 [acesso em 10 ago. 2017];25(1920):3049-57. Disponível em: https://onlinelibrary. wiley.com/doi/abs/10.1111/jocn.13365

9. Huded JM, Dresden SM, Gravenor SJ, Rowe $\mathrm{T}$, Lindquist LA. Screening for fall risks in the emergency department: a novel nursing-driven program. West J Emerg Med [Internet]. 2015 [acesso em 10 ago. 2017];16(7):1043-6. Disponível em: https://escholarship.org/uc/item/4rg7c7rh

10. Caldas CP, Veras RP, Motta LB, Guerra ACLC, Carlos MJ, Trocado CLM. Atendimento de emergência e suas interfaces: o cuidado de curta duração a idosos. J Bras Econ Saúde [Internet]. 2015 [acesso em 27 ago. 2017];7(1):62-9. Disponível em: http://files.bvs.br/ upload/S/2175-2095/2015/v7n1/a4757.pdf

11. Tenório DM, Camacho ACLF. Identificação dos agravos de saúde que levam os idosos ao serviço de emergência. Rev Enferm UFPE on line [Internet]. 2015 [acesso em 27 ago. 2017];9(1 Supl.):457-65. Disponível em: https://periodicos.ufpe.br/revistas/ revistaenfermagem/article/view/10359/11083

12. Bailey CJ, Murphyb R, Porockc D. Dying cases in emergency places: caring for the dying in emergency departments. Soc Sci Med [Internet]. 2011 [acesso em 12 nov. 2016];73(9):1371-7. Disponível em: https://www.sciencedirect.com/science/article/pii/ S0277953611005132?via\%3Dihub

13. Taylor BJ, Rush KL, Robinson CA. Nurses' experiences of caring for the older adult in the emergency department: a focused ethnography. Int Emerg Nur [Internet]. 2015 [acesso em 12 nov. 2016];23(2):185-9. Disponível em: http://www. internationalemergencynursing.com/article/S1755599X(14)00306-1/fulltext

14. Connel B, Hawkins M, Considine J, Au C. Referrals to hospital emergency departments from residential aged care facilities: stuck in a time warp. Contemp Nurse [Internet]. 2013 [acesso em 12 nov. 2016];45(2):228-33. Disponível em: https://www. researchgate.net/publication/259152303

15. Baumbusch J, Shaw M. Geriatric emergency nurses: addressing the needs of an aging population. J Emerg Nurs [Internet]. 2011 [acesso em 12 nov. 2016];37(4):3217. Disponível em: http://www.sciencedirect.com/ science/article/pii/S0099176710001868

16. Inzitari M, Gual N, Roig T, Colprim D, Bocanegra CP, José ASJ, et al. Geriatric screening tools to select older adults susceptible for direct transfer from the emergency department to subacute intermediatecare hospitalization. J Am Dir Assoc [Internet]. 2015 [acesso em 12 nov. 2016];16(10):837-41. Disponível em: https://www.sciencedirect.com/science/article/ pii/S1525861015003072?via\%3Dihub

17. Grossmann FF, Zumbrunn T, Ciprian S, Stephan FP, Woy N, Bingisser R, et al. Undertriage in older emergency department patients: tilting against windmills? Plos ONE [Internet] .2014 [acesso em 12 nov. 2016];9(8):1-7. Disponível em: http://journals.plos. org/plosone/article?id=10.1371/journal.pone.0106203

18. Misch F, Messmer AS, Nickel CH, Gujan M, Graber A, Blume K, et al. Impact of observation on disposition of elderly patients presenting to emergency departments with non-specific complaints. Plos one 2014 [acesso em 12 nov. 2016];9(5):1-7. Disponível em: https://pdfs.semanticscholar.org/7b3d/ c9c1dd74ec8720be623d59d29ad47923415a.pdf

19. Barros LM, Araújo TM, Neri MFS, Soares E, Caetano JA. Internação em uma unidade de emergência hospitalar: vivência. Cogitare Enferm [Internet]. 2013 [acesso em 14 ago. 2017];18(2):336-43. Disponível em: http://revistas.ufpr.br/cogitare/article/view/32583 
20. Dalawari P, Duggan J, Vangimalla V, Paniagua M, Armbrecht. Patient transfer forms enhance key information between nursing homes and emergency department. Geriatr Nurs [Internet]. 2011 [acesso em 26 out. 2016];32(4):270-5. Disponível em: http://www. gnjournal.com/article/S0197-4572(11)00266-7/fulltext

21. Olofsson P, carlstrom ED, Pettersson SB. During and beyond the triage encounter: chronically ill elderly patients' experiences throughout their emergency department attendances. Int Emerg Nurs [Internet]. 2012 [acesso em 26 out. 2016];20(4):207-13. Disponível em: http://www.internationalemergencynursing.com/ article/S1755-599X(12)00051-1/fulltext

22. Reis CCA, Sena ELS, Menezes TMO. Vivências de familiares cuidadores de pessoas idosas hospitalizadas e a experiência de intercorporeidade. Escola Anna Nery on line [Internet]. 2016 [acesso em 16 maio 2017];20(3):1-6. Disponível em: http://www.eean.edu. br/detalhe_artigo.asp?id=1429

23. Nogueira IS, Previato GF, Scolari GAS, Gomes ACO, Carreira L, Baldissera VDA. Intervenção domiciliar como ferramenta para o cuidado de enfermagem: avaliação da satisfação de idosos. Rev Gaúcha Enferm [Internet]. 2016 [acesso em 16 maio 2017];37(esp):1-7. Disponível em: http://seer.ufrgs. br/index.php/RevistaGauchadeEnfermagem/article/ view/68351/40827

24. Santos SC, Tonhom SFR, Komatsu RS. Saúde do idoso: reflexões acerca da integralidade do cuidado. Rev Bras Promoç Saúde [Internet]. 2016 [acesso em 16 maio 2017];29(Supl):118-27. Disponível em: http:// periodicos.unifor.br/RBPS/article/view/6413

25. Alves RLT, Silva CFM, Pimentel LN, Costa I A, Souza ACS, Coelho LAF. Avaliação dos fatores de risco que contribuem para queda em idosos. Rev Bras Geriatr Gerontol [Internet]. 2017 [acesso em 21 jun. 2017]; 20(1):59-69. Disponível em: http://www.scielo.br/pdf/ rbgg/v20n1/pt_1809-9823-rbgg-20-01-00056.pdf

26. Teixeira AL. Gestões de vida e morte: um olhar sobre o morrer no contemporâneo. Ayvu Rev Psicol [Internet]. 2016 [acesso em 21 jun. 2017];2(2):150-71. Disponível em: http://www.ayvu.uff.br/index.php/ AYVU/article/view/69/58

27. Paixão TCR, Campanharo CRV, Lopes MCBT, Okumo MFP, Batista REA. Dimensionamento de enfermagem em sala de emergência de um hospital-escola. Rev Esc Enferm USP [Internet]. 2015 [acesso em 27 ago. 2017];49(3):486-93. Disponível em: http://www. scielo.br/scielo.php?script $=$ sci_arttext\&pid $=$ S0080$62342015000300481 \& \operatorname{lng}=$ en\&nrm $=$ iso\&tlng $=$ pt
28. Silva CRL, Abraão FMS, Oliveira RC, Louro TQ, Moura LF, Silva RCL. Representações sociais de enfermeiros sobre o processo de morte e morrer em UTI. Cienc Cuid Saúde [Internet]. 2016 [acesso em 21 jun. 2017];15(3):474-81. Disponível em: http://www. periodicos.uem.br/ojs/index.php/CiencCuidSaude/ article/view/32345.

29. Street M, Considine J, Livingston P, Ottmann G, Kent B. In-reach nursing services improve older patient outcomes and access to emergency care [abstract]. Australas J Ageing [Internet]. 2015 [acesso em 14 out. 2016];34(2):115-20. Disponível em: http://onlinelibrary. wiley.com/doi/10.1111/ajag.12137/abstract

30. Koskenniemi J, Kilpi Hl, Suhonen R. Respect in the care of older patients in acute hospitals. Nurs Ethics [Internet]. 2012 [acesso em 26 nov. 2016];20(1):517. Disponível em: https://www.ncbi.nlm.nih.gov/ pubmed/23131699

31. Plant N, Mallit KA, Kelly P, Usherwood T, Gillespie $\mathrm{J}$, Boyages $\mathrm{S}$, et al. Implementation and effectiveness of 'care navigation', coordinated management for people with complex chronic illness: rationale and methods of a randomised controlled trial. BMC Health Serv Res [Internet]. 2013 [acesso em 12 nov. 2016];13:164. Disponível em: https://bmchealthservres. biomedcentral.com/articles/10.1186/1472-6963-13-164

32. Fry M, MacGregor C, Hyland S, Payne B, Chenoweth L. Emergency nurses' perceptions of the role of confidence, self-efficacy and reflexivity in managing the cognitively impaired older person in pain [abstract]. J Clin Nurs [Internet]. 2015 [acesso em 16 out. 2016];24(11-12):1622-9. Disponível em: http:// onlinelibrary.wiley.com/doi/10.1111/jocn.12763/abstract

33. Parke B, Hunter KF, Strain LA, Marck PB, Waugh $\mathrm{EH}, \mathrm{McClelland}$ AJ. Facilitators and barriers to safe emergency department transitions for community dwelling older people with dementia and their caregivers: a social ecological study. Int J Nurs Stud [Internet]. 2012 [acesso em 16 out. 2016];50(9):1206-18. Disponível em: http://www.journalofnursingstudies. com/article/S0020-7489(12)00403-8/fulltext

34. Taylor BJ, Rush KL, Robinson CA. Nurses' experiences of caring for the older adult in the emergency department: a focused ethnography. Internacional. Emerg Nurs [Internet]. 2015 [acesso em 25 out. 2016];23(2):185-9. Disponível em: http:// www.internationalemergencynursing.com/article/ S1755-599X(14)00306-1/fulltext 